International Journal of Instruction e-ISSN: 1308-1470 • www.e-iji.net

Article submission code: 20210416060356

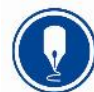

January $2022 \bullet$ Vol.15, No.1

p-ISSN: 1694-609X

pp. $473-488$

Received: $16 / 04 / 2021$

Revision: 08/07/2021
Accepted: 01/08/2021

OnlineFirst: 29/10/2021

\title{
The Effect of the Conflict Resolution Learning Model and Portfolio Assessment on the Students' Learning Outcomes of Civic Education
}

\section{Dewa Bagus Sanjaya}

Dr., Universitas Pendidikan Ganesha, Indonesia, bagus.sanjaya@undiksha.ac.id

I Kadek Suartama

Universitas Pendidikan Ganesha, Indonesia, ik-suartama@undiksha.ac.id

\section{Nengah Suastika}

Universitas Pendidikan Ganesha, Indonesia, nengah.suastika@undiksha.ac.id

\section{Sukadi}

Universitas Pendidikan Ganesha, Indonesia, sukadi.sukadi@ undiksha.ac.id

This study was aimed at investigating the effect of the conflict resolution learning model and portfolio assessment on students' learning outcome in civic education. This study was a quasi-experimental study using a sample of 120 students selected by applying multistage random sampling technique. This study used a $2 \times 2$ factorial design. The data were analysed by using ANOVA. The results showed that the civic education learning outcomes of the students who learned using the conflict resolution learning model were better than those of the students who learned using the conventional learning model, and the civic education learning outcomes of the students who were assessed using portfolio assessment were not different to those of the students who were assessed using objective assessment. Based on these findings, it is suggested that civic education lecturers, to improve the learning outcomes of the students in that subject, need to use appropriate learning models.

Keywords: conflict resolution learning model, portfolio assessment, civic education learning outcomes

\section{INTRODUCTION}

In addition to yielding a more democratic life, democratization has also resulted in a euphoria which is tumultuous and has a tendency to bring about several forms of violence and conflicts. Therefore, to be cautious is needed, and to overcome those conflicts and violence, a transformation of this nation's values which are derived from its outlook and principles is also needed. Democratic education as a means of civic education in the future is an education that is about, through, and for citizenship. It is also a means to foster this nation's character building (CICED, 2000).

Citation: Sanjaya, D. B., Suartama, I. K., Suastika, I. N., \& Sukadi. (2022). The effect of the conflict resolution learning model and portfolio assessment on the students' learning outcomes of civic education. International Journal of Instruction, 15(1), 473-488. https://doi.org/10.29333/iji.2022.15127a 
In line with that, civic education has socio-pedagogical, socio-academic, socio-cultural mission which enables integrated and continuous supervision and development of civic knowledge, civic virtues, and civic culture. Civic education also holds missions of learning democracy, in democracy, and for democracy (Winataputra \& Budimansyah, 2007). It basically aims to develop civic intelligence and civic participation of citizens of this nation (Cogan, 1998). Unfortunately, civic education up to the present only focuses on the importance of this subject without having positive socio-cultural implications for people's lives as members of a community, a nation, and a state (Sanjaya et al., 2021).

As a consequence, many citizens have understood the concepts, attitudes, norms, and values of Pancasila, the relationship between citizens and their state, their rights and obligations as well as initial state defense education, but limited to knowing or memorizing the theories only. Meanwhile, someone's understanding and insights, attitudes, confidence, commitment, and behavior in his/her life as a member of a community, a nation, and a state are not sufficient to be regarded as having good citizenship characters that this country can rely on (Abdulkarim et al., 2020). This is one of the main weaknesses of education in Indonesia. The improvement in theoretical knowledge which is not accompanied by improvement in students' life skills can give effects on students' learning outcomes.

There are three factors that can affect students' learning outcomes, namely: (1) internal factor, which is the factor that comes from within the students, (2) external factor, that is the factor that comes from outside the students, such as the condition of the environment around the students which includes family, school, surrounding environment, the available facility and learning sources, (3) learning approach, that is the strategy, method, or the learning techniques used by the teachers in the learning activity. Among those factors, the internal and learning approach are highly important factors in the learning process to improve students' learning outcomes (Suartama et al., 2019). The internal factors include physical and psychological conditions. Related to learning outcomes, the psychological condition has a very important role because learning is a mental process so that learning outcome is highly affected by the students' psychological factor. The psychological factors include interest, intelligence, attitude, talent, motivation, self regulated learning, and students' styles of thinking (Suartama et al., 2021).

After further analysis, it is known that the cause of the low activeness and learning outcomes of the students in civic education learning is that the developed learning organization and delivery is not yet able to make students motivated and challenged to learn optimally. This is proven by the learning outcomes of the students in civic education in the last two years; from 2017 until 2018, from 320 students only 110 of them $(36,25 \%)$ received A, while 141 of them received B, and 63 of them $(19,69 \%)$ received $\mathrm{C}$.

It was found out that the cause of this situation was the learning model that had been implemented was monotonous and teacher-centered so that tended to make students bored. One learning model that this study offers is the conflict resolution learning 
model. Education of conflict resolution is closely related to affective things, namely emotional control, anger, hostility, resentment, the development of the attitudes of being positive, tolerant, having sympathy, having empathy, realizing other people's perspectives, appreciating and caring towards other people, etc. (Maftuh, 2008).

A learning model has a close relationship with assessment technique. The assessment technique that has been implemented is the assessment that measures dominantly lowlevel cognitive aspects and has not yet directed towards the high-level cognitive aspects. Therefore, portfolio assessment is used in this study. Portfolio have been used systematically in education over the last few decades and are often understood as a collection of students' academic work, used to inform students' progress or achievements (Contreras-Soto et al., 2019). The portfolio is based on the following principles: (1) the assessment should be performance-based so that in addition to making use of the product assessment, assessment on the process has to get bigger attention, (2) students should be involved in every step of the assessment, (3) the assessment should give attention to students' self-reflection, (4) as the assessment needs to get big attention, portfolio assessment has to be used, and (5) reinforcement should be used maximally for the social and individual development of students (Joni, 1995).

\section{Context and Literature Review}

\section{Theoretical Framework}

\section{Civic Education}

Civic education, according to Muchtar (2001) has a strategic potential to be developed as democratic education, as etymologically, it develops values and awareness to build a nation of laws. The objective of a democratic country is to build awareness of democracy, knowledge on democracy mechanisms, such as democratic responsibility, transparency, peace, etc. Democratic civic education has been conducted in various forms, through formal education (school-based democracy education) and communitybased democracy education, that is conducted in the society. Civic education is an educational program, a multi-dimensional scientific study and it also functions as a socio-cultural action program in society (Winataputra \& Budimansyah, 2007).

The civic education that is more suitable to the reformation and democratization era is civic education as an education that is about, through, and for citizenship (Winataputra \& Budimansyah, 2007). Its vision is to create education as a means to build nation characters that are able to think globally, act locally and commit nationally (Komalasari \& Rahmat, 2019). Based on the opinions of experts in the above understanding, it can be stated that civic education is a subject that has the main focus in the formation of good citizens (good citizenship) who have the knowledge, skills, and values needed as guidelines for participating in society.

According to Winataputra (2001), the civic education basic strategies that have to be developed are utilizing various media and learning sources, interdisciplinary studies, social problem solving, social research, social actions, portfolio-based learning. 


\section{Conflict Resolution Learning Model}

Conflict resolution model is a learning model that can build students' ability and skills in responding and solving as well as taking actions on various phenomena and sociocultural issues that take place in the surrounding community (local, regional, national, international) based on the socio-cultural values of the community where they live and develop (Zuhdi, 2019).

The steps of the conflict resolution learning model as proposed by Ritiauw et al. (2018) are as follows: 1) identification, 2) exploration, 3) explanation, 4) conflict negotiation, and 5) conflict resolution. This conflict resolution learning model is based on a view that there is a causality relationship between social and cultural phenomena and the ability and social responsibility of an individual in society in a cycle that eventually makes human lives better and wealthy in harmony (Montgomery, 2000).

The conflict resolution model is a learning model that deemed relevant to be developed in realizing the goals of civic education. The best way for students to learn civic education is to expose them to challenging and stimulating problem solving methods thoughts, stimulate thinking habits, and take actions related to problem solving. In the conflict resolution learning process, students are faced with problems, then they are given information to build the problem, the problems faced by students after all the information is taught and explained in full. Conflict resolution by relying on the social and cultural values of the community in which they live and develop.

\section{Portfolio Assessment}

Arifin (2009) states that portfolio assessment is an approach or evaluation model that is intended to measure students' ability in building and reflecting an assignment/task through submission of relevant materials whose purposes and willingness are built by the learners and will be evaluated and commented by the teacher in a certain period. Hence, portfolio assessment is an approach to assess students' performance. While according to Budimansyah (2002), portfolio assessment is an effort to collect various information periodically, continuously, and thoroughly about the process and the development of students' knowledge, attitude, and skills, from the records and documentation of their learning experiences.

A portfolio is a compilation of students' works that is used to show students' efforts, success or learning achievements in a field or several fields (Stiggings, 1994). Substantially, a portfolio can be said as a picture of the results of writing, interpretation, as well as activities inside and outside the class (Popham, 1995). To lecturers, a portfolio is a compilation of documentation on students' learning progress. It has all the notes and students' works as well as their activities inside and outside the classroom in a certain period that is used as a proof or basis in giving a precise and objective assessment. Thus, a portfolio is defined as a compilation or collection of learning results, performance, and students' activities that are compiled systematically, and give proofs on the learning efforts, learning process, learning achievement/progress during the learning process. The work results can be in the form of test results, structured 
assignments, notes on students' daily behavior, and reports on students' activities inside and outside class that support their learning activities.

Portfolio assessment is considered relevant to the characteristics of civics education where civics education is to educate students and provide basic abilities to students to develop themselves according to their interests, talents, abilities, and environment, as well as provide provisions for students to continue to a higher level. The pattern of civic education emphasizes the elements of education and debriefing for students. The emphasis of this learning is not only limited to providing students with concepts in the form of rote.

\section{Hypothesis}

Based on the background, context and literature review above, then in this research the following hypothesis is formulated.

H-1: There are difference in the learning outcomes of civic education of the group of students learning using conflict resolution learning model and the group of students learning using conventional.

H-2: There are difference in the learning outcomes of civic education between the student group assessed using portfolio and the student group assessed using an objective test.

H-3: There are an effect of the interaction of learning model and type of assessment on the learning outcomes of civic education.

\section{METHOD}

\section{Research Design}

This study applied a quasi-experimental method with 2 x 2 factorial design (Fraenkel \& Wallen, 1993). This method was chosen as the data of this study was the difference of civic education learning outcomes after the treatment was given. The dependent variable was the students' learning outcomes. The independent variable was the learning model, which was differentiated into two groups, the conflict resolution learning model and the conventional learning model. The moderator variable was the type of assessment, which was divided into two types, portfolio and objective assessment. The research design is presented in Table 1.

Table 1

Experimental with $2 \times 2$ factorial design

\begin{tabular}{llll}
\hline \multicolumn{1}{c}{ Learning Model } & $\begin{array}{l}\text { Conflict Resolution Learning } \\
\text { Formative Assessment }\end{array}$ & $\begin{array}{l}\text { Conventional } \\
\text { Model (A2) }\end{array}$ & Learning \\
\hline Portfolio & $(\mathrm{X}, \mathrm{Y}) 11 \mathrm{k}$ & $(\mathrm{X}, \mathrm{Y}) 21 \mathrm{k}$ \\
$(\mathrm{B} 1)$ & $\mathrm{k}=1,2, \ldots, \mathrm{n} 11$ & $\mathrm{k}=1,2, \ldots, \mathrm{n} 21$ \\
$(\mathrm{~A})$ & $(\mathrm{A} 1 \mathrm{~B} 1)$ & $(\mathrm{X}, \mathrm{Y}) 22 \mathrm{k}$ \\
\hline Objective Test & $(\mathrm{X}, \mathrm{Y}) 12 \mathrm{k}$ & $\mathrm{k}=1,2, \ldots, \mathrm{n} 22$ \\
$(\mathrm{~B} 2)$ & $\mathrm{k}=1,2, \ldots, \mathrm{n} 12$ & $(\mathrm{~A} 2 \mathrm{~B} 2)$ \\
\hline
\end{tabular}




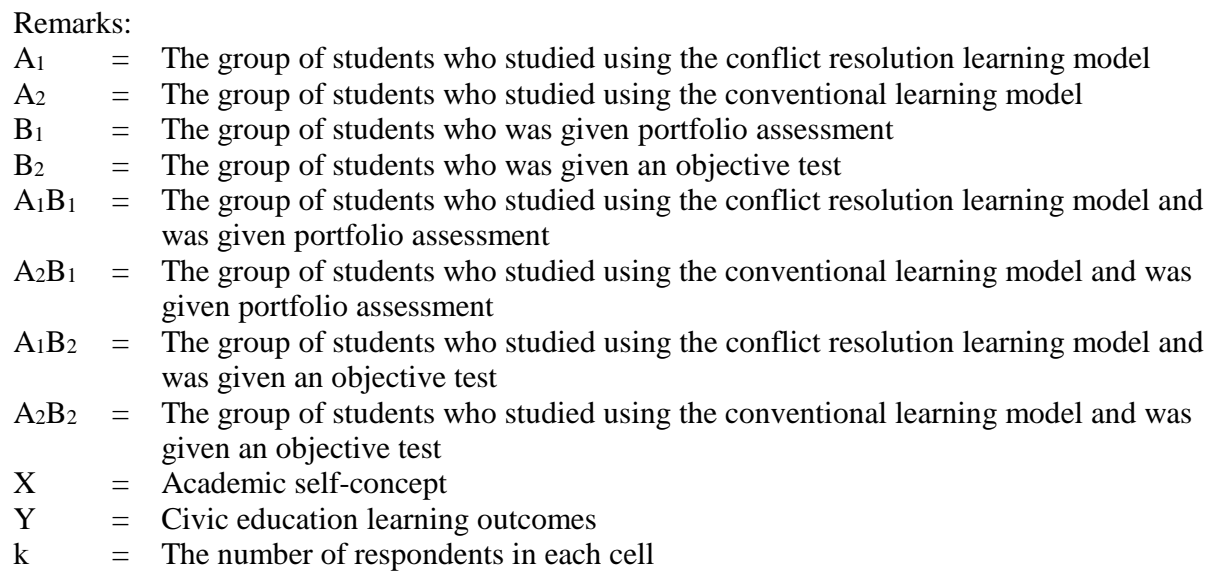

\section{Population and Sample}

The population in this study were all students in the first semester and first year (odd semester of 2017/2018) of the Elementary School Teacher Education Department, Faculty of Educational Sciences, Universitas Pendidikan Ganesha Singaraja-BaliIndonesia. The population of this research is 320 students. Firstly, the samples were determined by applying the multistage random sampling technique as stated by Creswell (2008). They were selected randomly from the 8 existing classes. The selected classes were class B, C, E, and G. Next, among those 4 classes, 2 were selected as experimental group and the other 2 were selected as the control group. The classes chosen as experimental classes were Class $\mathrm{C}$ and $\mathrm{G}$, while the ones chosen as control classes were class $\mathrm{B}$ and $\mathrm{E}$. The two classes which were chosen as experimental classes studied using the conflict resolution learning model in their learning, while the other two which were chosen as control classes used the conventional learning model. Thirdly, among the experimental classes, class $\mathrm{G}$ was chosen randomly to be given portfolio assessment, and class $\mathrm{C}$ was chosen randomly to be given objective test. Among the control classes, class $\mathrm{B}$ was chosen randomly to be given portfolio and class $\mathrm{E}$ was chosen randomly to be given objective test. The students in one class were also randomized to result in an even number of samples, that was 30 students. The classes chosen as samples are presented in Table 2.

Table 2

The distribution of samples that are classified based on the classes

\begin{tabular}{llll}
\hline No & Class & Number of Students & $\begin{array}{l}\text { Number of Students after being } \\
\text { Randomized }\end{array}$ \\
\hline 1 & G & 34 & 30 \\
\hline 2 & B & 35 & 30 \\
\hline 3 & C & 36 & 30 \\
\hline 4 & E & 32 & 30 \\
\hline Total & & 137 & 120 \\
\hline
\end{tabular}




\section{Treatment Design}

The treatment for experimental and control groups was given in the same condition; the materials, the number of meetings, and the teaching staff were relatively the same. The steps of the learning activity in the experimental group or the group that studied using the conflict resolution model in this study were as follows.

1. Identification, which consisted of: explaining the objective of the learning, question and answer to explore the concepts that the students already had, giving examples of conflicts/ issues/problems.

2. Exploration, which consisted of: checking the personal values of the people involving in the problems, question and answer about the conflicts presented, presentation of the learning materials, identification of the conflicts presented earlier, searching for reading resources to support problem-solving.

3. Explanation, which consisted of: formulating a hypothesis about the conflicts being taught, searching for responsible parties/institutions and the ones that had authority to deal with the conflicts, clarification on the concepts that the students already had to strengthen the cognitive factor, creating a team to discuss further things, and testing the hypothesis that had been given.

4. Negotiating conflict, which consisted of: the lecturers supervising the discussion, supervising students in expressing their ideas, assisting students to collect the information needed, reports from each team, and conclusion of the discussion results.

5. In the following meeting, the students presented their works in turn for 10-15 minutes.

6. The lecturers asked the students that did not take roles as presenters to give comments and suggestions on the presentation

7. The lecturers gave feedback based on the portfolio and students' performance until all students had got their chances.

8. During the learning process, the observers (the lecturers that did not teach/supervise) observed the students' learning activity in a group or individually by using the observation sheet provided by the teaching team.

9. The lecturer closed the meeting.

10. Reflection, which was done a moment after the learning took place. This activity was led by a moderator who was appointed from one of the observers.

11. Refection, which was started with a short presentation on the learning that had been done by the lecturer.

12. Every observer would give his/her views, suggestions, or advices based on the observation results on the students' learning activity during the learning. In this reflection, every participant was given a sheet that contained the rules of how the reflection should be carried out.

13. The results of the reflection were used as materials to compose the learning activity for the following meeting.

While in the control group, the learning method applied was the one that had been normally used (conventional), namely lecture and question and answer method. 


\section{Instrument}

The study instrument is the conflict model and the portfolio assessment. Data collection instrument used in this study was the learning result test of civic education. The civic education learning outcomes in this study were knowledge, understanding, and or skills that were known by or had by the students about the learning materials after going through the learning process for a certain period of time. The learning outcomes were in the form of scores/numbers, which were obtained from the test of civic education given at the end of the study.

\section{Data Analysis}

The statistical analysis used to test the hypothesis of this study was ANOVA A/B or two-way ANOVA with 5\% significance level. This analysis model was used to test the difference in the parameter of the mean of civic education learning outcomes of all student groups that attended the class with the learning model and given assessment. The procedure of the two-way ANOVA analysis was used to: (1) test the difference in civic education learning outcomes of all student groups based on the learning model, (2) test the difference in civic education learning outcomes of all student groups based on the type of formative assessment, (3) test the effect of the interaction between the learning model and type of formative test on the learning outcomes of civic education.

\section{FINDINGS}

The results of this study include a description of the research data, the results of the analysis of pre-requisite tests, and the results of the analysis of hypothesis testing.

The data description in Table 3 below is the results of the A/B ANOVA test.

Table 3

Data description on the research result

\begin{tabular}{lllll}
\hline \multicolumn{1}{c}{ Model } & $\begin{array}{l}\text { Types of } \\
\text { Assessment }\end{array}$ & Mean & Std. Deviation & $\mathrm{N}$ \\
\hline Conflict Resolution & Portfolio & 60.36 & 5.01 & 30 \\
\hline & Objective & 53.00 & 5.16 & 30 \\
\hline Conventional & Total & 56.68 & 6.26 & 60 \\
\hline & Portfolio & 50.93 & 4.64 & 30 \\
\hline Total & Objective & 55.10 & 5.20 & 30 \\
\hline & Total & 53.01 & 5.32 & 60 \\
\hline & Portfolio & 55.65 & 6.75 & 60 \\
\hline & Objective & 54.00 & 5.24 & 60 \\
\hline
\end{tabular}

As presented in table 3 , data analysis was continued by conducting a pre-requisite test. namely normality and variance homogeneity tests. The results of the normality test are presented in table 4. 
Table 4

Normality test of data distribution

\begin{tabular}{lllllll}
\hline \multicolumn{3}{c}{ Kolmogorov-Smirnov(a) } & \multicolumn{3}{l}{ Shapiro-Wilk } \\
\hline & Statistic & Df & Sig. & Statistic & df & Sig. \\
\hline $\begin{array}{l}\text { Standardized } \\
\begin{array}{l}\text { Residual for } \\
\text { Results }\end{array}\end{array}$ & 0.054 & 120 & $0.200(*)$ & 0.985 & 120 & 0.209 \\
\hline
\end{tabular}

The result of the Kolmogorov-Smirnov test indicated that the significance value that was gained was bigger than the significance level $\alpha=0.05$, with samples from a normally distributed population. Further, the data variance homogeneity test is presented in table 5.

Table 5

Data variance homogeneity test

\begin{tabular}{llll}
\hline $\mathrm{F}$ & $\mathrm{df} 1$ & df2 & Sig. \\
\hline 0.294 & 3 & 116 & 0.829 \\
\hline
\end{tabular}

Tests the null hypothesis that the error variance of the dependent variable is equal across groups.

a Design: Intercept+Model+Evaluasi+Model * Evaluasi

As presented in table 5, the value of sig. was 0.829. This was bigger than the significance level $\alpha=0.05$, which means that the data were homogeneous. After both assumptions, normality and variance homogeneity were met a hypothesis test was conducted. The hypothesis was tested using two-way variance analysis. The results of the two-way ANOVA analysis test are presented in table 6.

Table 6

Summary of two-way ANOVA

\begin{tabular}{llllll}
\hline Source & $\begin{array}{l}\text { Type III Sum of } \\
\text { Squares }\end{array}$ & df & Mean Square & F & Sig. \\
\hline Corrected Model & $1477.767(\mathrm{a})$ & 3 & 492.59 & 19.65 & 0.000 \\
\hline Intercept & 361022.700 & 1 & 361022.70 & 14403.49 & 0.000 \\
\hline Model (A) & 403.333 & 1 & 403.33 & 16.09 & 0.000 \\
\hline Assessment (B) & 76.800 & 1 & 76.80 & 3.06 & 0.083 \\
\hline Model * Assessment & 997.633 & 1 & 997.63 & 39.80 & 0.000 \\
\hline Error & 2907.533 & 116 & 25.06 & & \\
\hline Total & 365408.000 & 120 & & & \\
\hline Corrected Total & 4385.300 & 119 & & & \\
\hline
\end{tabular}

a R Squared $=.337$ (Adjusted R Squared $=.320)$

The results of the two-way ANOVA test indicated that the value of $\mathrm{F}$ in model (A) was $F_{\text {count }} 16.092$, while the $F_{\text {table }}$ value for $\mathrm{dfA}=1$ and $\mathrm{df}_{\text {within }}=116$ with significance level 0.05 was 3.92 . The $F_{\text {count }}$ was bigger than the $F_{\text {table. The significance value gained was }}$ 0.000 , smaller than the significance level that had been determined, that was $\alpha=0.05$. 
This means that there was difference on the learning outcomes of civic education between students learning using conflict resolution learning model and conventional model.

The results of the two-way ANOVA test indicated that the value of $\mathrm{F}$ in assessment (B) was $F_{\text {count }} 3.064$, while the $F_{\text {table }}$ for $\mathrm{df} A=1$ and $\mathrm{df}_{\text {within }}=116$ with significance level

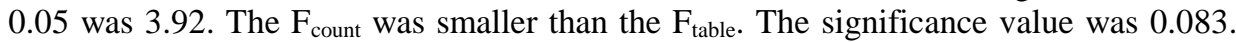
which was bigger that the significance level $\alpha=0.05$. This means that there was no difference in the learning outcomes of civic education between students assessed using portfolio assessment and objective assessment.

In column Model*Assessment. the value of $\mathrm{F}_{\text {count }}$ was 39.802 and $\mathrm{F}_{\text {table }}$ for $\mathrm{df} \mathrm{A}=1$ and $\mathrm{df}_{\text {within }}=116$ with significance level 0.05 was $3.92 . \mathrm{F}_{\text {count }}$ was bigger than $\mathrm{F}_{\text {table. The }}$ significance value (sig.) gained was 0.000 , smaller than the significance level $\alpha=0.05$. This means that there was a significant interaction between the learning model and type of assessment and the learning outcomes of civic education.

\section{DISCUSSION}

The results of the study are discussed according to the research hypothesis as follows.

\section{Hypothesis One: The Civic Education Learning Outcomes of the Group of Students Learning Using the Conflict Resolution Learning Model were Higher than Those of the Students Learning Using the Conventional Model}

The hypothesis testing indicated that this research hypothesis that stated that there was difference in the learning outcomes of civic education of the group of students learning using conflict resolution learning model and the group of students learning using conventional way was accepted. The results indicated that the learning outcomes of the group of students learning using the conflict resolution learning model were higher than those of the students learning using the conventional learning model. after their selfconcept of academics was controlled. Conflict resolution learning is essentially a more powerful learning in encouraging students' participation in democratic social life. Referring to the democratic principles of conflict resolution learning. not only teaching about democracy, but it also teaches in a democratic situation. The conflict resolution learning model emphasizes students' sensitivity in solving problems democratically to achieve the goal of learning (Ay et al., 2019). In line with that. Branson (1999) asserts that conflict resolution learning can strengthen the competencies of civic knowledge, civic dispositions, and civic skills of citizens. Bodin \& Crawford (1995) state that conflict resolution in education can build moral judgment and moral reasoning.

In addition to building students' awareness and social intelligence, conflict resolution learning also maintains group' solidarity in solving problems. Conflict resolution learning can also improve students' individual chances in managing conflicts. and give chance to students to make a connection between interpersonal and social conflict. which is very important in preparing them to be good citizens (Kathy, 1999). The conflict resolution learning model improves students' skills in communicating, solving problems, thinking critically, making decisions, and improving other social skills such as 
appreciating diversity, showing empathy, collaborating and digging as well as expressing their feelings (Nancy E, 1999). Conflict resolution can play an important role in educating students in discipline supported by their understanding and awareness of the causes of the conflicts. Such education is expected to prevent students from getting involved in violence and anti-social behavior. Thus, conflict resolution can play an important role as a preventive program. In a group solidarity context. Slavin (1995) states that cooperative learning trains students to take roles as peer-tutors in a team, appreciate others' opinions in a team, and appreciate team members in studying.

Through conflict resolution. learning can take place systematically, starting from identification, exploration, explanation, negotiation, and conflict resolution. Its implementation in class is: students identify the socio-cultural problems in their own community, that are related to the learning materials; active involvement of the students in searching for and formulating information that can be used to negotiate and solve the conflicts in their social community; students use electronic as well as local, regional, and national media to obtain information that can be used to solve conflicts; focuses on the effects of the information on social and culture for students; extension of students' learning limit and time that goes beyond the limits of class and school environment (broader and deeper instructions); the learning material is not limited to facts, concepts and generalizations that have to be mastered by students, but it also emphasizes process skills that can be used by students to negotiate and solve daily problems (Suartama et al., 2020); provides optimum chance to students to play their roles as members of society, nation and state when they are able to identify and formulate the social conflicts that they face; emphasizes the autonomy of learners in learning process and their capacity as individuals (personal ability); in learning. it also emphasizes students' identification ability and skills on the socio-cultural conflicts in their society in the future. All learning process leads students to be able to make a decision or accurate and comprehensive actions for the socio-cultural conflicts that take place in the society. The conflict resolution learning process needs collaboration and synergy between lecturers and students in understanding conflicts, principles of conflict resolutions, steps in conflict prevention and skills in conflict resolution. In line with conflict resolution, if someone wants to improve his/her learning, one of the ways that he/she can take is collaborating with his/her lecturers or teachers in designing, observing, and reflecting on the learning that he/she has done (Susilo, 2009).

Hence, it can be concluded that conflict resolution learning is better in improving students' learning outcomes compared to the conventional learning model.

\section{Hypothesis Two: No Difference was Shown in the Learning Outcomes between the Student Group Assessed using Portfolio and the Student Group Assessed using an Objective Test}

In learning, assessment is an important part that cannot be separated from the learning itself (Divayana et al., 2021). The learning and material characteristics need an appropriate type of assessment so that learning can be done well and can achieve the objectives. Objective (conventional) assessment in civic education is a type of assessment that has been commonly used by lecturers in assessing the students. The 
weakness of this type of assessment is that it is not appropriate to be used to assess complex students' learning outcome behavior. Such assessment in the context of civic education. emphasizes the cognitive aspect more dominantly. It has not developed students' competencies holistically yet. As stated by Anderson \& David R. Krathwohl (2008), for other purposes (not limited to informal assessment) teachers use certain learning activities as assignments that will be assessed. Such activities are meant to help students in learning and to access their learning. They have double functions; for learning and assessment. Even though they can be used to evaluate students. they are actually also formative tests whose main objective is to lead students "to the right track". To be able to direct students to the right path (processed learning), correct information is needed about the development of ability related to the learning process. Fisher \& Frey (2007) explain that finding out students' understanding is not done at the end of the test. From the evidence on the students' understanding, the scores obtained in a collection of assessments can be known. To examine or check students' understanding is a systematic approach in assessment. Hence, the assessment is an ongoing assessment that includes a review process and observation in class. Further. it is explained that assessment is used by teachers to improve their learning methods and provide feedback along the teaching and learning process. Those theories show that the suitable assessment for those objectives is portfolio assessment. At the end of a period, the portfolio is compiled and scored by the teachers and the students themselves.

The results of the study indicated that there was no difference in the learning outcomes between the students assessed using portfolios and the students assessed using objective assessment. This was due to several causes: 1) in portfolio assessment, the emphasis was on the final achievement, so the process did not receive enough attention; 2) portfolio assessment was relatively new, so it was not yet known and understood well; 3) the class was relatively big and it took a lot of time to score. Hatta et al., (2004) state that portfolio assessment is not really reliable and fair, students are normally stuck in a topdown relationship, where the lecturers are considered the ones who know everything the most, and students are considered objects that should be told about something. Another important cause is that the unavailability of assessment criteria.

Hypothesis Three: There was an Effect of the Interaction of Learning Model and Type of Assessment on the Learning Outcomes of Civic Education

The third hypothesis testing in this study indicated that there was an effect of the interaction between learning model and assessment type on the learning outcomes of civic education after students' academic self-concept was controlled. This study showed that there was an effect of interdependent relationship between the learning model and assessment type and civic education learning outcomes. This was proven by the results

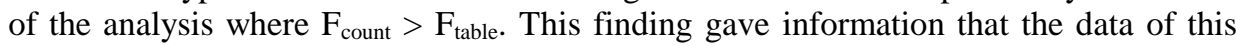
research supported the hypothesis that had been proposed. The conclusion was strengthened by corrected average score gained, which indicated that reciprocal relationship effect was evident.

The hypothesis testing in this study was supported by the theory that in the learning process, there are two important things that learners need to pay attention to. First, what 
is taught and how it is taught. The material for learners should be delivered using appropriate/creative methods/ways. For example, using a learning model that is appropriate with the characteristics of the competencies that will be mastered or in line with the characteristics of the materials. Second. how to assess or evaluate the learners' learning improvement. In this context, the assessment implemented has to be in line with the characteristics of the learning competency achievement indicator. Therefore, an appropriate method or instrument is needed. An appropriate time to assess learners' development has to be considered. For example, whether the assessment is conducted during the learning or in every part of every basic competency/a certain coverage of material. Most important of all is how the results of the assessment are followed up for the improvement of the learning. This is in line with the study by Joyce et al., (2011) who explains about social learning principles and theoretical foundation that is also known as behaviour modification, behavior therapy, or cybernetics. The principle states that humans are self-correcting communication systems that can change their behavior when responding to information about how successful they are in doing their tasks (Joyce et al., 2011). This principle implicitly suggests the relation between learning and assessment, which is shown by the feedback given during the learning process that affects the behavior change of learners as a response to the improvement given by them. In this context, the learning outcomes of the learners are very much determined by tests and learning models. Based on the results of the hypothesis testing and the discussion on the theories above, it can be concluded that the learning outcomes of civic education will be achieved effectively and maximally if the assessment that is given to the learners is in line with their learning process habits

\section{CONCLUSION}

The implementation of the conflict resolution learning model was able to improve the learning outcomes of democratic education compared to the conventional learning model, but no significant difference was shown in terms of the learning outcomes between the students assessed by using portfolio assessment and those assessed by using an objective assessment. In addition, there was an effect of the interaction between the learning model and type of assessment on the students' civic education learning outcomes.

\section{SUGGESTIONS}

For civic education lecturers, it is necessary to consider the use of conflict resolution learning models as an alternative strategy in teaching civic education. Therefore, lecturers need to learn in order to be able to design, develop, and manage this learning strategy by optimizing the stages and principles of the conflict resolution learning model. In connection with the interaction between learning models and types of assessment, educational institutions are expected to make policies to improve the quality of learning, especially in developing learning strategies and assessments that are more student-oriented. For further research, the combination of learning models and the relationship with the type of assessment can be explored more deeply. Portfolio assessment can be reused to conduct research with independent variables/other learning models. Further research needs to examine the relationship between the conflict 
resolution learning model and portfolio assessment with other more interesting aspects, such as learning efficiency and learning attractiveness.

\section{REFERENCES}

Abdulkarim, A., Komalasari, K., Saripudin, D., Ratmaningsih, N., \& Anggraini, D. N. (2020). Development of a unity in diversity-based pancasila education text book for Indonesian universities. International Journal of Instruction, 13(1), 371-386. https://doi.org/10.29333/iji.2020.13125a

Anderson, L. W., \& David R. Krathwohl, K. (2008). Kerangka Landasan Untuk Pembelajaran, Pengajaran, dan Penilaian. Pustaka Pelajar.

Arifin, Z. (2009). Evaluasi Pembelajaran Prinsip Teknik Prosedur. PT Remaja Rosdakarya.

Ay, Ş. Ç., Keskin, H. K., \& Akilli, M. (2019). Examining the effects of negotiation and peer mediation on students' conflict resolution and problem-solving skills. International Journal of Instruction, 12(3), 717-730. https://doi.org/10.29333/iji.2019.12343a

Bodin, R. J., \& Crawford, D. K. (1995). Developing Emotional Intelligence A Guide to Behavior Management and Conflict Resolution in Schools. Research Press.

Branson, M. S. (1999). Making the Case for Cicvic Education: Where We Stand at the End of the 20th Century. CCE.

Budimansyah, D. (2002). Model Pembelajaran dan Penilaian Portofolio. PT. Genesindo.

CICED. (2000). Final Report: A Needs-Assessment for New Indonesian Civic Education: A National Survey. https://civiced.org/civitas/program/research-andevaluation/indonesia

Cogan, J. J. (1998). Citizenship education for the 21st century: setting the context. In J. J. Cogan \& R. Derricott (Eds.), Citizenship education for the 21st century: an international perspective on education. Kogan Page.

Contreras-Soto, A., Véliz-Campos, M., \& Véliz, L. (2019). Portfolios as a strategy to lower English language test anxiety: The case of Chile. International Journal of Instruction, 12(1), 181-198. https://doi.org/10.29333/iji.2019.12112a

Creswell, J. W. (2008). Education Research: Planing, Conducting, and Evaluarting Quantitative and Qualitative Research. Pearson Merrill Prentice Hall.

Divayana, D. G. H., Sudirtha, I. G., \& Suartama, I. K. (2021). Digital Test Instruments Based on Wondershare-Superitem for Supporting Distance Learning Implementation of Assessment Course. International Journal of Instruction, 14(4), 945-964. https://doi.org/10.29333/iji.2021.14454a

Fisher, D., \& Frey, N. (2007). Checking for Understanding. Formative Assessment Techniques for Your Classroom. Association for Supervision and Curriculum 
Development.

Fraenkel, J. R., \& Wallen, N. E. (1993). How to Design and Evaluate Research in Education. McGraw-Hill Inc.

Hatta, Surapranata, \& Sumarna. (2004). Penilaian Portofolio Implementasi Kurikulum 2004. Remaja Rosdakarya.

Joni, T. R. (1995). Penilaian Hasil Belajar Melalui Pengalaman dalam Program S1 Kedua Pendidikan Bidang Studi SD. Konsorsium Ilmu Pendidikan, Depdikbud, Ditjen Dikti.

Joyce, B., Weil, M., \& Calhoun, E. (2011). Models of Teaching. Model-model Pengajaran, terjemahan Ahmad Fawaid dan Ateilla Mirza. Pustaka Pelajar.

Kathy, B. (1999). Preparation for Pluralism: curricular and extracurricular practice with conflict resolution. Theory Into Practice, 36(1).

Komalasari, K., \& Rahmat. (2019). Living Values Based Interactive Multimedia in Civic Education Learning. International Journal of Instruction, 12(1), 113-126. https://doi.org/https://doi.org/10.12973/iji.2018.11127a

Maftuh, B. (2008). Pendidikan Resolusi Konflik Membangun Generasi Muda yang Mampu Menyelesaikan Konflik Secara Damai. UPI, Sekolah Pasca Sarjana.

Montgomery, R. (2000). Revolution of Learning How We Enhance Students Achievement. Journal a Scientific Education, 19(1), 45-51. https://kagan.olam.asu.edu/epaa

Muchtar, S. Al. (2001). Epistimologi Pendidikan Ilmu Pengetahuan Sosial. Gelar Pustaka Mandiri.

Nancy E, T. (1999). The Impact of Conflict Resolution Education on Partisipating Students and their families: a qualitative case study. : College of Educatin, Ohio State University.

Popham, W. J. (1995). Classroom Assessment: What Teachers Need to Know. Allyn \& Bacon- A Simon \& Schuster Company.

Ritiauw, S. P., Maftuh, B., \& Malihah, E. (2018). Model of Conflict Resolution Education Based on Cultural Value of Pelaq in Social Studies Learning. Advances in Social Science, Education and Humanities Research (ASSEHR), 147(Icsse 2017). https://doi.org/10.2991/icsse-17.2018.66

Sanjaya, D. B., Suartama, I. K., Suastika, I. N., Sukadi, \& Dewantara, I. P. M. (2021). The implementation of balinese folflore-based civic education for strengthening character education. Cypriot Journal of Educational Sciences, 16(1), 303-316. https://doi.org/https://doi.org/10.18844/cjes.v16i1.5529

Slavin, R. E. (1995). Cooperative Learning: Theory, Research, and Practice. Allyn and Bacon. 
Stiggings, R. J. (1994). Student Centered Classroom Research and Development. Heinemann.

Suartama, I. K., Setyosari, P., Sulthoni, \& Ulfa, S. (2019). Development of an instructional design model for mobile blended learning in higher education. International Journal of Emerging Technologies in Learning, 14(16). https://doi.org/10.3991/ijet.v14i16.10633

Suartama, I. K., Setyosari, P., Sulthoni, Ulfa, S., Yunus, M., \& Sugiani, K. A. (2021). Ubiquitous Learning vs . Electronic Learning: A Comparative Study on Learning Activeness and Learning Achievement of Students with Different Self-Regulated Learning. International Journal of Emerging Technologies in Learning (IJET), 16(03), 36-56. https://doi.org/https://doi.org/10.3991/ijet.v16i03.14953

Suartama, I. K., Triwahyuni, E., Sukardi, A., \& Hastuti, W. D. (2020). Development of E-Learning Oriented Inquiry Learning Based on Character Education in Multimedia Course. European Journal of Educational Research, 9(4), 1591-1603. https://doi.org/10.12973/eu-jer.9.4.1591

Susilo, H. (2009). Lesson Studi Berbasis Sekolah: Guru Konservatif Menuju Guru Inovatif. Bayumedia Publlishing. https://onesearch.id/Record/IOS4317.laser-120000528

Winataputra, U. S. (2001). Jatidiri Pendidikan Kewarganegaraan sebagai Wahana Pendidikan Demokrasi. UPI.

Winataputra, U. S., \& Budimansyah, D. (2007). Civics Education Konteks: Landasan, Bahan Ajar dan Kultur Kelas. Program Studi Pendidikan Kewarganegaraan UPI. http://kin.perpusnas.go.id/DisplayData.aspx?pId=77052\&pRegionCode=UNES\&pClien $\mathrm{tId}=634$

Zuhdi, M. H. (2019). Local Wisdom of Sasaknese Society as A Model of Conflict Resolution. ASEAN/Asian Academic Society International Conference 2019, January 2000, 521-527. http://aasic.org/proc/aasic/article/view/527 